Environmental Research Journal 5 (2): 49-58, 2011

ISSN: 1994-5396

(C) Medwell Journals, 2011

\title{
Approaches to Olive Mill Wastewater Treatment and Disposal in Cyprus
}

\author{
${ }^{1}$ Christos C. Anastasiou, ${ }^{1}$ Petros Christou, ${ }^{1}$ Antonis Michael, \\ ${ }^{1}$ Demetris Nicolaides and ${ }^{2}$ Theofanis P. Lambrou \\ ${ }^{1}$ Department of Civil Engineering, Frederick University 7 , \\ Y. Frederickou Str., Pallouriotissa, 1036 Nicosia, Cyprus \\ ${ }^{2}$ Department of Electrical and Computer Engineering, \\ University of Cyprus, Nicosia, Cyprus
}

\begin{abstract}
This study discusses the issues related to disposal of Olive Mill Wastewater (OMWW) in Cyprus and approaches to economically and environmentally acceptable treatment of the waste. Processes to reduce the toxicity of OMWW and make it acceptable for disposal onto soil or into receiving waters were reviewed. OMWW has a high chemical oxygen demand is acidic and is phytotoxic. Olive oil extraction plants in Cyprus are small and seasonal and their OMWW wastes would most appropriately be treated biologically. Three biological approaches, aerobic treatment, anaerobic treatment and composting are reviewed in this study. In each case, advantages and disadvantages of the processes are discussed. Current practices for OMWW disposal and pertinent regulations, as well as a set of questions that need to be addressed in order to design an efficient treatment system for Cyprus are outlined. Finally, recommendations for further research to develop a cost-effective and efficient process for remediation of OMWW are made.
\end{abstract}

Key words: Olive mill wastewater, biological treatment of agricultural wastewater, Cyprus agriculture, aerobic treatment, phytotoxic, acceptable

\section{INTRODUCTION}

Global olive production exceeds 15 million metric tons per year, from which over 2.5 million metric tons of olive oil is produced, generating an estimated $10-30$ million $\mathrm{m}^{3}$ of Olive Mill Wastewater (OMWW) (Niaounakis and Halvadakis, 2006). The dark coloration, high biological and chemical oxygen demand (BOD/COD) and presence of phytotoxic substances make direct discharge of OMWW into freshwater and coastal areas or onto land impossible. In addition, the seasonal nature of olive oil production and presence of antimicrobial chemicals in OMWW (e.g., phenolics and long chain fatty acids) complicate the search for efficient and economically feasible treatment processes.

In 2004, Cyprus produced 27,500 metric tons of olives. There are approximately 35 olive mills in Cyprus generating about 7500 tons year $^{-1}$ of olive oil. The objectives of this study are three-fold; first, to review the current state of knowledge regarding OMWW remediation, second, to determine the most promising methods for treating OMWW in Cyprus and three, to outline a development program leading to implementation of these methods.

\section{OLIVE MILL WASTEWATER}

Wastewater composition: Multiple methods are used in the production of olive oil and these result in differing waste products. Pressure systems and 3-phase centrifugation systems produce substantially more OMWW than 2-phase centrifugation (which produces large amounts of semi-solid or slurry waste). The following discussion of OMWW composition pertains specifically to that generated by pressure and 3-phase centrifugation systems.

OMEE is generally characterized by dark coloration, high $\mathrm{BOD} / \mathrm{COF}$, low $\mathrm{pH}$ and the presence of phytotoxic and antimicrobial compounds. Wide ranges of all of these characteristics have been reported and the composition of OMWW varies substantially not only by region but also by the type of process used, daily usage conditions and local operational procedures (Table 1) (Niaounakis and Halvadakis, 2006).

The organic components of OMWW consist primarily of sugars and phenolics. Sugars reported in OMWW include fructose, mannose, glucose, saccharose, sucrose and pentose. Phenolic compounds are present in olive stones and pulp tend to be more soluble in the

Corresponding Author: Christos C. Anastasiou, Department of Civil Engineering; Frederick University, Nicosia, Cyprus 
Table 1: Variation in reported, selected, characteristics of OMWW from olive press and centrifugation systems (Niaounakis and Halvadakis, 2006)

\begin{tabular}{lcc}
\hline Parameters & Pressure systems & Three-phase centrifugation \\
\hline pH & $4.2-7.0$ & $4.7-5.3$ \\
Total solids $\left(\mathrm{g} \mathrm{L}^{-1}\right)$ & $28-126$ & $14-45$ \\
Oil $\left(\mathrm{g} \mathrm{L}^{-1}\right)$ & 2.26 & 5.78 \\
Total phenols $\left(\mathrm{g} \mathrm{L}^{-1}\right)$ & 6.2 & 2.7 \\
Ash $\left(\mathrm{g} \mathrm{L}^{-1}\right)$ & 20 & 6.4 \\
$\mathrm{COD}\left(\mathrm{g} \mathrm{L}^{-1}\right)$ & $6.4-162$ & $25-78$ \\
BOD $\left(\mathrm{g} \mathrm{L}^{-1}\right)$ & $1.5-100$ & $13-44$ \\
TKN $\left(\mathrm{g} \mathrm{N} \mathrm{L}^{-1}\right)$ & $0.09-3.2$ & $0.02-0.64$ \\
Total phosphorus $\left(\mathrm{g} \mathrm{P} \mathrm{L}^{-1}\right)$ & Trace -1.1 & Trace-0.16 \\
Potassium (mg L & 17100 & 9800 \\
Sodium $\left(\mathrm{mg} \mathrm{L}^{-1}\right)$ & 400 & 160 \\
Calcium $\left(\mathrm{mg} \mathrm{L}^{-1}\right)$ & 2240 & 1350 \\
Magnesium $\left(\mathrm{mg} \mathrm{L}^{-1}\right)$ & 2720 & 1650 \\
Iron (mg L & 129 & 33 \\
\hline
\end{tabular}

water phase than oil. Phenolics are found in OMWW in concentrations ranging from $0.5-25 \mathrm{~g} \mathrm{~L}^{-1}$. About $>30$ different phenolic compounds have been identified in OMWW and the types and concentrations of phenolics reported in OMWW vary tremendously (Niaounakis and Halvadakis, 2006). However, hydroxytyrosol, caffeic acid and various flavonoids have all been reported in substantial quantities. The main inorganic component of OMWW is potassium.

Effects of OMWW on the environment: Discharge of OMWW directly onto soil has a significant impact. Effects of the physical properties of soil are mixed. OMWW reduces soil porosity thereby limiting the exchange of air and water between the soil and atmosphere. However, polysaccharides in OMWW may increase soil aggregate stability and decrease rates of soil erosion. OMWW also has a significant impact on soil chemistry. Despite the low $\mathrm{pH}$ of OMWW (approximate $\mathrm{pH}=5$ ), it has little lasting effect on soil $\mathrm{pH}$. However, OMWW can cause mobilization of heavy metals from soil and sediments. Additionally, the high $\mathrm{C} / \mathrm{N}$ ratio in OMWW can stimulate and alter the soil microbial community which can lead to competition for nitrogen between soil microorganisms and plants. Finally, phenolic compounds in OMWW are phytotoxic and can inhibit plant seed germination.

OMWW also has significant impacts when discharged directly into surface waters. The high concentration of darkly colored polyphenols in OMWW can discolor streams and rivers. In addition, the high concentration of reduced sugars can stimulate microbial respiration, lowering dissolved oxygen concentrations, while the high phosphorus content can lead to eutrophication. OMWW has also been shown to be toxic at low levels to crustaceans and fish.
About $10 \%$ of OMWW in Cyprus is discharged in treatment facilities; $85 \%$ is stored in ponds or discharged directly onto soil. Discharge of OMWW into sewage systems is problematic. OMWW contains high pollutant load $\left(1 \mathrm{~m}^{3}\right.$ OMWW $=100-200 \mathrm{~m}^{3}$ of domestic sewage $)$. Additionally or ganic acids contained in OMWW are highly corrosive and damage sewage pipes. OMWW discharged into holding ponds can create significant odor problems. Gases such as methane and hydrogen sulfide emanate form the ponds. Additionally, over one-half of the COD from such ponds is due to the presence of volatile fatty acids in cluding caproic, valeric is obutyric acids.

General use/disposal options for treated OMWW: The high organic and phenolic content and dark color of OMWW make disposal difficult. Effective bioremediation resulting in significant reductions in COD, phenolics and color should allow safe and economical disposal of OMWW onto land or into surface waters. Additionally, bioremediation may be used to produce valuable products. Several studies have demonstrated that bioremediated OMWW is an excellent fertilizer (Cereti et al., 2004) and can serve as a substrate for nitrogen-fixing bacteria or be used to produce polysaccharides (Balis et al., 1996).

Disposal of OMWW in Cyprus: The Law for the Pollution Control of Waters and Soil (No. 106(I)/2002) is the governing law in the Republic of Cyprus that aims to protect surface water, groundwater and the soil from human and industrial activities, as well as control liquid and solid industrial wastes. The Law which is broken down into nineteen Regulating Adminstrative Actions (RAA's), harmonizes the Cyprus legislation frame research to the EU directives and decisions. The most relevant RAA's to olive oil production are shown in Table 2. Additionally, there are also eleven ordinanances of which those relevant to olive oil production are shown in Table 3.

The principal Ordinance regulating the disposal of Olive Oil Production Waste is the Waster Pollution Control (Waste Disposal Permit) Ordinance of 2003 (254/2003). The waste streams generated by olive mills as well as the application for the disposal permit differ according to the process used for the oil extraction (i.e., two-phase or three-phase centrifugation). Consequently, the types and amounts of waste allowed to be deposited for each process differ (Table 4).

As described in the ordinance, regardless the type of process they originate from (two-phase or three-phase) liquid wastes (wastes types $\mathrm{a}$ and $\mathrm{b}$ in Table 4) should be temporarily stored in waterproof sealed tanks. 
Environ. Res. J., 5 (2): 49-58, 2011

Table 2: Regulating Administrative Actions (RAA) in cyprus legislation associated with olive oil production

\begin{tabular}{lll}
\hline RAA & Regulations & Publication date \\
\hline $407 / 2002$ & Code for good agricultural practice & September 6, 2002 \\
$517 / 2002$ & $\begin{array}{l}\text { Water pollution control (Use of sludge } \\
\text { in agriculture) Regulations of 2002 }\end{array}$ & November 1, 2002 \\
$534 / 2002$ & $\begin{array}{l}\text { Water pollution control (Nitrogen } \\
\text { pollution of agricultural origin) } \\
\text { Regulations of 2002 }\end{array}$ & November 8, 2002 \\
& \\
\hline
\end{tabular}

Table 3: Ordinances in cyprus legislation associated with olive oil production

\begin{tabular}{lll}
\hline Ordinances & Description & Publication date \\
\hline $45 / 1996$ & $\begin{array}{l}\text { Water pollution control (Groundwater } \\
\text { protection measures) Ordinance of 1996 }\end{array}$ & February 23, 1996 \\
254/2003 & $\begin{array}{l}\text { Water pollution control (Waste disposal } \\
\text { permit) Ordinance of 2003 }\end{array}$ & November 1, 2002 \\
$41 / 2004$ & $\begin{array}{l}\text { Water pollution control } \\
\text { (Action program for the Nitrogen }\end{array}$ & January 30, 2004 \\
$42 / 2004$ & $\begin{array}{l}\text { Sensitive regions of Cyprus) } \\
\text { Nitrogen sensitive zones and } \\
\text { water categories that are subjected } \\
\text { or are possible to be subjected to } \\
\text { Nitrogen pollution }\end{array}$ & January 30, 2004 \\
& & \\
\hline
\end{tabular}

Table 4: Maximum annual waste quantities allowed for two- and threephase centrifuge olive mills in Cyprus

\begin{tabular}{lcc}
\hline & $\begin{array}{c}\text { Maximum annual waste } \\
\text { quantities allowed }\left(\mathrm{m}^{3}\right)\end{array}$ \\
\cline { 2 - 3 } & $\begin{array}{l}\text { Two-phase } \\
\text { centrifuge }\end{array}$ & $\begin{array}{c}\text { Three-phase } \\
\text { centrifuge }\end{array}$ \\
$\begin{array}{l}\text { Waste stream generated } \\
\text { Liquid waste from the washing of olives }\end{array}$ & 180 & 1600 \\
$\begin{array}{l}\text { Liquid waste (water and minimal olive } \\
\text { oil mill wastewater) originating from } \\
\text { the centrifuging decanters where the }\end{array}$ & 1400 & 1400 \\
$\begin{array}{l}\text { separation of the plant liquids of the } \\
\text { fruit from the oil takes place }\end{array}$ & & \\
$\begin{array}{l}\text { Sludge (olive dregs) originating from } \\
\text { the horizontal centrifuging decanter }\end{array}$ & 750 & \\
$\begin{array}{l}\text { Sludge settling at the liquid wastes } \\
\text { evaporation tanks/ponds }\end{array}$ & - & - \\
Leaves from defoliation & - & - \\
\hline
\end{tabular}

Whether or not the streams are mixed or separated depends on the method of disposal. Additionally, sludge (olive dregs-type c) should be temporarily stored in a covered area with concrete base (platform). Liquids originating from leakages or run-offs from the temporary storage areas for the solid wastes or sludge should be collected and transferred to the liquid wastes tanks, via open-air waterproof pipes.

Liquid waste from the washing of the olives (waste stream a) can be used for irrigation of cultivations (trees, forest-trees, etc.) surrounding the olive mill. In cases where the waste is mixed with liquid waste originating from the centrifuging decanters (b), the liquid wastes must be transferred for final disposal in evaporations tanks/ponds. Evaporation tanks must be open, waterproof, earthen and shallow (maximum depth of $1.2 \mathrm{~m}$ ). Liquid wastes must be transferred to the evaporation tank within closed pipes or with a tanker.
Table 5: Characteristics of liquid waste entering the evaporation tank

\begin{tabular}{lc}
\hline Parameters & Maximum value allowed \\
\hline $\mathrm{pH}$ & $5.0-7.0$ \\
Electric conductivity & $10,000 \mu \mathrm{S} \mathrm{cm}^{-1}$ \\
Suspended solids & $5,000 \mathrm{mg} \mathrm{L}^{-1}$ \\
BOD & $10,000 \mathrm{mg} \mathrm{L}^{-1}$ \\
Fat & $6,000 \mathrm{mg} \mathrm{L}^{-1}$ \\
Phenols & $1,000 \mathrm{mg} \mathrm{L}^{-1}$ \\
\hline
\end{tabular}

The required quality (maximum allowance) of the liquid wastes to be disposed in the evaporation tank is shown in Table 5.

Sludge produced by the decanter of a two-phase mill must be collected and transferred by a tanker to the appropriate facilities for incineration of composting. At the end of functioning period, no sludge should be present at the temporary storage area. Solid wastes produced by a three-phase mill must be collected and used as animal stocking or fertilizer or sent to a seed-oil production facility for further treatment. The institution exploiting the waste should maintain a database for the quantities and the ways the waste has been disposed. If the olive dregs are used as soil improver (fertilizer), the application should be at least $300 \mathrm{~m}$ from residential areas, with a maximum disposal rate of 3.5 tons/hectare/year.

Sludge depositing at the bottom of the evaporation tanks should be collected, when needed after the liquid present in the tank has been dried and transferred for disposal to an approved public area or as soil improver (under the conditions stated above). Additional permit conditions include requirements that:

- The Environment Service of the Republic of Cyprus should be informed immediately, if there is a leakage

- An annual report of the olive quantities treated, the amounts of wastes generated and the scheme of waste management

- The temporary storage and the evaporation tanks/ ponds must be easily accessed for sample collection and check-ups

\section{MICROORGANISMS FOR THE BIOREMEDIATION OF OMWW}

A variety of processes (aerobic or anaerobic bioreactors, composting) and microorganisms (bacteria and fungi) have been tested to treat OMWW to remove the dark coloration, reduce the organic load and remove phytotoxic compounds.

Aerobic microorganisms: Research into the use of aerobic remediation of OMWW has been carried out 
using both bacteria and fungi. A number of different bacteria have been tested in aerobic processes to treat OMWW in cluding Bacillus pumilus (RamosCormenzana et al., 1996), Arthrobacter (Knupp et al., 1996), Azotobacter vinelandii (Papadelli et al., 1996; Ehaliotis et al., 1999; Piperidou et al., 2000), Pseudomonas putida and Ralstonia sp. (Di Gioia et al., 2001) and various bacterial consortia (Ranalli, 1992; Zouari and Ellouz, 1996a, b; Benitez et al., 1997).

Aerobic bacteria have been tested primarily to remove phytotoxic compounds (i.e., monoaromatic or simple phenolics) from OMWW although some studies have also focused on reduction of Chemical Oxygen Demand (COD). The bacteria appear to have a minimal effect on more complex polyphenolics responsible for the dark coloration of OMWW. The effectiveness of the aerobic bacteria in this process varies greatly. Furthermore, they appear to be very effective against some phenolic compounds and relatively ineffective against others. For example, B. pumilus was able to completely degrade protocatechuic acid caffeic acid but had much less effect on tyrosol (Ramos-Cormenzana et al., 1996). On the other hand, Arthrobacter transformed tyrosol to 4-hydroxyphenyl acetic acid (Knupp et al., 1996).

Several studies of bioremediation of OMWW in Greece have focused on Azotobacter vinelandii. Papadelli et al. (1996) isolated a strain of $A$. vinelandii from soil treated with OMWW. Eventually, $>90 \%$ removal of phytotoxic compounds from OMWW was achieved using this strain (Ehaliotis et al., 1999; Piperidou et al., 2000). Di Gioia et al. (2001) used two bacteria, Ralstonia sp. and Pseudomonas putida to treat Italian OMWW. Cultured together, these bacteria were able to degrade a number of phenolic compounds found in OMWW.

A number of studies have utilized bacterial consortia for bioremediation of OMWW. The consortia have come from activated sludge (Benitz et al., 1997), commercial consortia (Ranalli, 1992), soil and wastewater (Zouri and Ellouz, 1996a, b). Bioremediation of OMWW using aerobic consortia has been quite successful achieving significant reductions in the total concentration of phytotoxic compounds and complete removal of some simple phenolics.

De Felice et al. (1997) used a combination of bacteria and yeast to degrade OMWW. The yeast, Yarrowia lipolytica, reduced the COD of OMWW by $80 \%$ in $24 \mathrm{~h}$, leaving aromatic compounds undegraded. Effluent from the yeast fermentation was then treated with Pseudomonas putida, producing further reduction of COD and removal of aromatics in 12-16 h.
Table 6: Effectiveness of white rot fungi for bioremediation of OMWW Maximum percent removal Total

\begin{tabular}{lcccl} 
Fungus & COD & phenolics & Color & Reference \\
\hline Coriolus versicolor & 63 & 90 & 65 & Yesilada et al., 1998 \\
Geotric um candidum & 52 & - & 70 & Assas et al., 2000 \\
Funalia trogii & 40 & 77 & 38 & Yesilada et al., 1995 \\
& 70 & 93 & 81 & Yesilada et al., 1998 \\
Lentinula & 75 & 66 & 45 & Vinciguerra et al., 1995 \\
(Lentinus edodes & 88 & 89 & 75 & D'Annibale et al., 1998 \\
Phanerochaete & 80 & - & 74 & Say adi and Ellouz, 1992 \\
chrysosporium & 64 & 70 & 67 & Kissi et al., 2001 \\
Phanerochaete & - & 90 & 70 & Ben Hamman et al., 1999 \\
flavido-alba & & & & \\
Pleurotus sp. & - & 76 & - & Tsioulpas et al., 2002 \\
Pleurotus eryngii & - & $>90$ & - & Sanjust et al., 1991 \\
Pleurotus floridae & - & $>90$ & - & Sanjust et al., 1991 \\
Pleurotus ostreatus & - & $>90$ & - & Sanjust et al., 1991 \\
& - & 100 & - & Tomati et al., 1991 \\
Pleurotus sajor-caju & - & $>90$ & - & Sanjust et al., 1991 \\
\hline
\end{tabular}

Fungal remediation of OMWW has been achieved using three types of organisms: white rot fungi (including the edible mushrooms Lentinula and Pleurotus), Aspergillus sp. and several different yeasts. IN addition to reduction of COD and removal of simple phenolics, fungi are also effective at reducing coloration of OMWW. A variety of white rot fungi have been used for remediation of OMWW in cluding Coroilus versicolor and Funalia trogii (Yesilada et al., 1995, 1998), Geotrichum candidum (Assas et al., 2000), Lentinula (Lentinus) edodes (Vinciguerra et al., 1995, 1997; D'Annibale et al., 1998) and Phanaerochaete sp. (Sayadi and Ellouz, 1992; Ben Hamman et al., 1999).

A number of studies have examined the ability of the edible white rot fungus Pleurotus to degrade OMWW (Sanjust et al., 1991; Tomati et al., 1991; Kissi et al., 2001; Tsioulpas et al., 2002). The white rot fungi appear quite effective, achieving removal rates as high as $88 \%$ for COD, $100 \%$ for phenolics and $81 \%$ for coloration (Table 6).

Use of Aspergillus for bioremediation of OMWW has not been as common as the white rot fungi. Hamdi in a number of studies, characterized the ability of Aspergillus niger to degrade OMWW (Hamdi et al., 1991a, b; Hamdi and Ellouz, 1992a, b). Reduction of COD and phenol concentrations $>60 \%$ were achieved using A. niger. Similar reductions in COD and phenolics were found using Aspergillus terreus (Nieto et al., 1993).

Yeasts used in the bioremediation of OMWW include Trichosporon cutaneum (Chtourou et al., 2004), Nadida tropicalis (Ettayebi et al., 2003) and Saccharomyces sp. (Gharsallah, 1993). Like the other fungi, these yeasts were effective at reduction of $\mathrm{COD}$ and removal of monoand polyphenols. 
Two studies have compared the effectiveness of different types of fungi for the bioremediation of OMWW. Fadil et al. (2003) compared Geotrichum sp., Aspergillus sp. and Candida tropicalis. Reduction of COD (55-63\%) and phenolics (44-52\%) was similar for all three fungi. Garcia et al. (2000) compared two white rot fungi (Phanerochaete chrysosporidium and Geotrichum candidum) and two species of Aspergillus (A. niger and A. terreus). No removal of phenols was observed for G. candidum. For the other organisms, the efficiency of the removal of total phenols relative to the total organic load consumed occurred in the order $P$. chrysosporidium $>A$. niger $>A$. terreus.

Anaerobic microorganisms: Anaerobic bioremediation of OMWW has employed, almost exclusively, uncharacterized microbial consortia derived from municipal and other waste facilities (Rozzi et al., 1989; Martin et al., 1991; Borja et al., 1996; Dalis et al., 1996; Fiestas Ros de Ursinos and Borja-Padilla, 1996; Zouari and Ellouz, 1996; Marques et al., 1997; Marques, 2001). Two significant advantages of anaerobic processes over aerobic may be the generation of methane which could potentially be used in remediation or as an energy source for other processes and the production of a much smaller quantity of sludge (Fiestas Ros de Ursinos and BorjaPadilla, 1996).

Reductions in COD from $70-89 \%$ have been reported for anaerobic processes (Borja et al., 1996; Marques et al., 1997; Marques, 2001). In addition to a substantial reduction on COD, Dalis et al. (1996) reported large reductions $(>75 \%)$ in the concentrations of both toxic phenols and volatile fatty acids using a two stage anaerobic reactor with an inoculant obtained from a domestic wastewater facility. However, it is difficult to evaluate the effectiveness of phenolic reduction inthis case because the researchers did not report information on the types of phenolic compounds that were degraded or the methods used to assay for phenolics. In contrast, other studies have reported that the build up of recalcitrant phenolics (e.g., condensed tannins) (Zouari and Ellouz, 1996) as well as the presence of long chain fatty acids (Hwo and Lettinga, 1997) in anaerobic reactors inhibited bacterial activity.

The presence of compounds toxic to methanogenic bacteria on OMWW appears to be a significant problem for anaerobic digestion of OMWW. One approach to the problem has been to dilute the OMWW to reduce the concentration of phenolics and fatty acids. However, this results in the need to treat a substantially larger volume of wastewater. A number of studies have examined the use of aerobic pretreatment of OMWW to remove compounds that are toxic to methanogenic bacteria. Aerobic pretreatment has been primarily studied using two organisms: Aspergillus sp. And white rot fungi. Hamdi (1991) found that pretreatment of OMWW with $A$. niger more than doubled methane production in subsequent anaerobic digestion. In other studies, anaerobic digestion after pretreatment with $A$. niger removed over $60 \%$ of COD and resulted in high methane yields (Hamdi et al. 1992). Similarly, studies using $A$. terreus have demonstrated that aerobic pretreatment greatly reduced the concentration of phenolics and significantly increase methane production (up to $23 \%$ ). Two different white rot fungi have been used in the pretreatment of OMWW prior to anaerobic digestion, with different results. Pretreatment with $P$. chrysosporidium reduced the COD of OMWW but apparently had little effect on polyphenolics that remained in the effluent and inhibited subsequent methane production (Gharsallah et al., 1999). However, pretreatment with $G$. candidum reduced the COD, phenolic and volatile fatty acid content of OMWW and increased substrate uptake during anaerobic digestion (Martin et al., 1993).

Borja et al. (1998) compared anaerobic digestion of OMWW pretreated by two different fungi and a bacterium: G. candidum, A. terreus and Azotobacter chroococcum. These organisms decreased the phenolic concentration and toxicity of OMWW by 59,87 and $79 \%$, respectively. One interesting factor of note from this study as well as others is that while the white rot fungi appear to the most effective microorganisms in aerobic treatment processes (i.e., superior to Aspergillus and bacteria) they are the least effective organisms for pretreating OMWW for anaerobic digestion.

Enzymatic treatment: A small number of studies have examined the enzymes produced by white rot fungi involved in bioremediation of OMWW. Perez et al. (1998) demonstrated that OMWW induced manganese peroxidase and laccase production in Phanerochaete flavido-alba. A comparison of OMWW decolorization by lignin peroxidase and manganese peroxidase produced by $P$. chrysosporium demonstrated that lignin peroxidase was a much more effective at breaking down polyphenolics (produced 70\% decolorization of the OMWW) (Sayadi and Ellouz 1995). D'Annibale et al. (2000) found that immobilized laccase from L. edodes was efficient in reduction of total phenols. However, the decolorizing effect was substantially lower (approximately 20\%) than reported for lignin peroxidase. 


\section{BIOREACTORS USED FOR DIRECT OMWW TREATMENT}

Bioreactor technology which could be applied to remove organic pollutants (measured as chemical oxygen demand) from OMWW is based on either aerobic or anaerobic bioreactor configurations. Aerobic systems are generally not regarded as being suitable for direct OMWW treatment, however, as the presence of inhibitors, such as phenols, prevent the successful growth of aerobic bacteria. Furthermore, aerobic bioreactor configurations, such as activated sludge or sequencing batch reactors are energy intensive, require high nutrient inputs to support treatment are complex to maintain and operate, produce large quantities of waste biomass and have high capital construction costs (Gray, 1999). These are particularly significant points for treatment of relatively small-scale OMWW streams.

A variety of anaerobic bioreactor types have been employed for the treatment of OMWW, although most of the available operations data has been generated at laboratory or pilot-scale. There are several potential advantages with this approach including the production of a usable biogas fuel (typical yields of $7-8 \mathrm{~m} \mathrm{~m}^{-3}$ OMWW), low waste biomass generation $(0.15-0.25 \mathrm{~kg}$ $\mathrm{kg}^{-1}$ COD removed) and the generation of an excellent soil conditioner and fertilizer (Lettinga, 1995; Niaounakis and Halvadakis, 2006). A number of basic bioreactor designs have been employed in cluding suspended biomass systems, such as the Upflow Anaerobic Sludge Blanket (UASB), the Anaerobic Baffled Reactor (ABR), upflow and gravity-flow filters and the fluidized bed. More recently, a number of researcher have reported the development of granular activated carbon-based bioreactor systems, both simple packed-bed bioreactors (Bertin et al., 2006) and more complex, moving bed systems (e.g., EP324314, 1989).

In order to overcome the poor availability of nitrogen in OMWW and to stabilize bioreactor $\mathrm{pH}$, concentrated ammonia was often added to the OMWW for experimental purposes. A number of authors have also successfully anaerobically co-digested the OMWW with swine manure (Angelidaki and Ahring, 1997; Angelidaki et al., 2002) and dairy effluents (Gavalla et al., 1996), an approach which is potentially attractive as low-cost nutrients are provided for digestion in hibitory compounds present in the OMWW are diluted and the digester can be operated on a year-round basis (Gavalla et al., 1996; Angelidaki and Ahring, 2002).

The initial trials on direct anaerobic biotreatment of OMWW were carried out using Completely Stirred Tank
Reactor (CSTR) configurations and anaerobic contact bioreactors. However, a number of features including the requirement for mechanical mixing and the need for prolonged (10-25 days) Hydraulic Retention Times (HRTs) make these systems unattractive for full-scale applications. A number of trials have also been carried out with second generation bioreactors. For example, stable performance has been reported in laboratory-scale UASB bioreactors at Organic Loading Rates (OLRs) of 5-18 $\mathrm{kg} \mathrm{m}^{-3}$ day (Boari and Mancini, 1990; Zouari and Ellouz, 1996b; Ubay and Ozturk, 1997) with COD removal efficiency of approximately $75 \%$ at HRTs of 1-2 days. Khabbaz et al. (2004) reported stable and efficient COD removal in an ABR bioreactor system but at a maximum OLR of only $2.5 \mathrm{~kg} \mathrm{~m}^{-3}$ day. The use of an anaerobic filter which combines a UASB and an anaerobic filter for treatment of diluted OMWW was reported by BorjaPadilla for treatment of wash water derived from the purification of virgin olive oil with encouraging results (COD removal efficiencies of $>89 \%$ at an OLR of $17.9 \mathrm{~kg} \mathrm{~m}^{-3}$ day and a HRT of $4.8 \mathrm{~h}$ ).

A number of multi-phase anaerobic digester configurations have also been employed. For example, the aquatecOLIVIA process is a two-phase anaerobic treatment approach, consisting of an initial acidification step (HRT 2.5 days) and a second methanogenic stage using a moving bed reactor (HRT 8 days), with hollow cylindrical supports as a carrier. A semi-pilot process was installed in Crete in 1999 and achieved COD removal efficiencies of 92-97\% at imposed OLRs (Niaounakis and Halvadakis, 2006). A second pilot configuration involving an upflow-sludge bed and ana anaerobic filter operated in series was described by Dalis et al. (1996) and achieved a combined 91\% COD removal efficiency at an OLR of $11 \mathrm{~kg} \mathrm{~m}^{-3}$ day. The use of two state systems is potentially attractive asa degree of phase separation can be achieved for example, saturation of long-chain fatty acids and acidification would predominate in the first phase, allowing efficient methanogenesis of the acidified stream in the second phase.

Composting of OMWW: In addition to the use of bioreactors, composting has been used to treat OMWW. The most common methodology employed has been the Rutgers Strategy (Finstein et al., 1985). A number of different bulking agents have been used in compost with OMWW in cluding solid olive and olive tree waste (Papadimitriou et al., 1997; Vlyssides et al., 1999), wheat straw (Tomati et al., 1995; Galli et al., 1997), maize straw (Paredes et al., 1996) and cotton waste (Paredes et al., 2002). Composting typically results in complete reduction of phytotoxicity in a few weeks (Paredes et al., 1996). 
Parades et al. (2000) compared different composts for treatment of OMWW using cotton waste or maize straw as bulking agents and poultry manure, municipal waste or industrial waste from orange juice extraction as nutrient sources. At the end of composting, the germination index of all treatments was over $50 \%$ in dicating reduction of phytotoxicity. The wide range of bulking agents and other wastes that can be successfully composted with OMWW suggest that this is a versatile technology that could be utilized and adapted to local conditions in Cyprus or elsewhere in the Mediterranean region.

\section{CONCLUSION}

There are approximately 35 olive mills in Cyprus generating 26,000 tons year ${ }^{-1}$ of olive mill wastewater. OMWW is characterized by dark coloration, high organic content and phytotoxicity, all of which prohibit direct discharge into freshwater and coastal areas or onto land. Remediation of OMWW is a significant problem in all olive oil producing countries. However, despite the scale of the problem and significant research investment, disposal of OMWW remains a serious problem.

Different OMWW treatment processes have been tested by scientists in the olive oil producing countries of the Mediterranean region. The effectiveness and efficiency of these methods varies widely. Regional differences in the composition of OMWW (due to geographical and climatic conditions, tree age, olive type, extraction technology used, use of pesticides and fertilizers, harvest time and stage of maturity) indicate the need to specifically address OMWW produced in Cyprus, especially in view of the fact that the current practice for management of OMWW is still limited to the use of evaporation ponds and the subsequent discharge of solid residue in landfills and/or on soil. While evaporation ponds offer a good way to reduce the liquid portion of the waste, they do very little in reducing the toxicity of the waste, while they simultaneously impart an odor problem to the areas where such waste is stored. Furthermore, evaporation results in the loss of large quantities of water which is often an important and limited resource in Cyprus and in other olive oil producing countries.

\section{RECOMMENDATIONS}

The extreme variation in the character of OMWW, based on the process of oil extraction as well as geoclimatic conditions that may exist in the area of olive production, makes a unified treatment method difficult. Further, since such a treatment system will be used in agricultural areas in, often, small and seasonal operations, it should conform to certain basic characteristics. For instance, such a treatment process should be efficient, cost effective and site-specific that takes into consideration the seasonal and spatial character of olive oil production. The process should reduce the environmental impact of the wastewater and will conserve natural resources essential to the region (e.g., valuable and scarce water).

This study has presented a detailed overview of the completed research surrounding the biological treatment (bioremediation) of olive mill wastewater. However, a number of questions concerning treatment of olive mill wastewater remain to be answered. Some questions that even after this review/research, would be interesting to be answered are provided below:

- What is responsible for the antimicrobial/inhibitory properties of OMWW-simple phenolics or polyphenols? What is the role of fatty acids?

- What is the cause of variation in the effectiveness of different treatments? Organisms effective in some studies are not effective in others. Is this a result of differences among strains or of differences on the composition of OMWW?

- The white rot fungi and particularly $P$. chrysosporium are among the most effective organisms in aerobic treatment. However, $P$. chrysosporium was ineffective in pretreating $\mathrm{OMEE}$ for anaerobic digestion. Likewise, G. candidum was much less effective in pretreatment than other organisms. Is there a toxic component (for methanogens) not removed by the white rot fungi?

- What are the components of OMWW that are potentially toxic/inhibitory to microorganisms?

- What is the ability of different microorganisms in dividually and in combination, to tolerate and/or remove microbially toxic/inhibitory chemicals?

- What are the microorganisms that are the most effective at reducing $\mathrm{COD}$, removing phytotoxic phenols and reducing the dark color (polyphenols) of OMWW?

- How well do treatment methods that have been traditionally used in municipal wastewater (i.e., extended aeration) may lend themselves for the treatment of OMWW?

\section{REFERENCES}

Angelidaki, I. and B.K. Ahring, 1997. Codigestion of olive mill wastewaters with manure, household waste or sewage sludge. Biodegradation, 8: 221-226.

Angelidaki, I., B.K. Ahring, H. Deng and J.E. Schmidt, 2002. Anaerobic digestion of olive oil mill effluents together with swine manure in UASB reactors. Water Sci. Technol., 45: 213-218. 
Assas, N., L. Marouani and M. Hamdi, 2000. Scale down and optimizxation of olive mill wastewaters decolorization by Geotrichum candidum. Bioprocess Biosyst. Eng., 22: 503-507.

Balis, C., J. Chatzipavlidis and F. Flouri, 1996. Olive mill waste as a substitute for nitrogen fixation. Int. Biodeteriorat. Biodegradat., 38: 169-178.

Ben Hamman, O., T. de la Rubia and J. Martinez, 1999. Decolorization of olive mill wastewaters by Phanerochaete flavido-alba. Environ. Toxicol. Chem., 18: 2410-2415.

Benitez, J., J. Belrtan-Heredia, J. Torregrosa, J.L. Acero and V. Cercas, 1997. Aerobic degradation of olive mill wastewaters. Applied Microbiol. Biotechnol., 47: 185-188.

Bertin, L., C. Colao, M. Ruzzi, L. Marchetti and F. Fava, 2006. Performances and microbial features of an aerobic packed-bed biofilm reactor developed to post-treat an olive mill effluent from an anaerobic GAC reactor. Microbiol. Cell Fact., 5: 5-16.

Boari, G. and I.M. Mancini, 1990. Combined treatments of urban and olive mill effluents in Apulia, Italy. Water Sci. Technol., 22: 235-240.

Borja, R., J. Alba and C.J. Banks, 1996. Anaerobic digestion of waste waters derived from the purification of virgin olive oil using hybrid reactor combining a filter and sludge blanket. Process Biochem., 31: 219-224.

Borja, R., J. Alba, A. Mancha, A. Martin, V. Alonso and E. Sanchez, 1998. Comparative effect of different aerobic pretreatments on the kinetics and macroenergetic parameters of anaerobic digestion of olive mill wastewater in continuous mode. Bioprocess Biosyst. Eng., 18: 127-134.

Cereti, C.F., F. Rossini, F. Federici, D. Quanatino, N. Vassilev and M. Fenice, 2004. Reuse of microbially treated olive mill wastewater as fertilizer for wheat (Triticum durum Desf.). Bioresour. Technol., 91: 135-140.

Chtourou, M., E. Ammar, M. Nasri and K. Medhioub, 2004. Isolation of a yeast, Trichosporon cutaneum, able to use low molecular weight phenolic compounds: Application to olive mill waste water treatment. J. Chem. Technol. Biotechnol., 79: 869-878.

D'Annibale, A., C. Crestini, V. Vinciguerra and G.G. Sermanni, 1998. The biodegradation of recalcitrant effluents from an olive mill by a white-rot fungus. J. Biotechnol., 61 : 209-218.

Dalis, D., K. Anagnostidis, A. Lopez, I. Letsiou and L. Hartmann, 1996. Anaerobic digestion of total raw olive-oil wastewater in a two-stage pilot-plant (Up-flow and fixed-bed bioreactors). Bioresour. Technol., 57: 237-243.
De Felice, B., G. Pontecorvo and M. Carfagna, 1997. Degradation of waste waters from olive mills by Yarrowia lipolytica ATCC 20255 and Pseudomonas putida. Acta Biotechnol., 17: 231-239.

Di Gioia, D., L. Bertin, F. Fava and L. Marchetti, 2001. Biodegradation of hydroxylated and methoxylated benzoic, phenylacetic and phenylpropeoinic acids present in olive mill wastewater by two bacterial strains. Res. Microbiol., 152: 83-93.

D'Annibale, A., S.R. Stazi, V. Vinciguerra and G.G. Sermanni, 2000. Oxirane immobilized Lentinula edodes laccase: Stability and phenolics removal efficiency in olive mill wastewtater. J. Biotechnol., 77: 265-273.

Ehaliotis, C., K. Papadopoulou, M. Kotsou, I. Mari and C. Balis, 1999. Adaptation and population dynamics of Azobacter vinelandii during aerobic biological treatment of olive-mill wastewater. FEMS Microbiol. Ecol., 30: 301-311.

Ettayebi, K., F. Errachidi, L. Jamai, M.A. Tahri-Jouti, K. Sendide and M. Ettayebi, 2003. Biodegradation of polyphenols with immobilized Candida tropicalis under metabolic induction. FEMS Microbiol. Lett., 223: $215-219$.

Fadil, K., A. Chahlaoui, A. Ouahbi, A. Zaid and R. Borja, 2003. Aerobic biodegradation and detoxification of wastewaters from the olive oil industry. Int. Biodeteriorat. Biodegradat., 51: 37-41.

Fiestas Ros de Ursinos, J.A. and R. Borja-Padilla, 1996. Biomethanization. Int. Biodet. Biodegr., 38: 145-153.

Finstein, M.S., F.C. Miller, S.T. MacGregor and K.M. Psarianos, 1985. The rutgers strategy for composting: Process design and control. United States Environmental Protection Agency Report EPA/600/S2-85/059.

Galli, E., L. Pasetti, F. Fiorelli and U. Tomati, 1997. Olive mill wastewater composting: Microbiological aspects. Waste Manage. Res., 15: 323-330.

Garcia, I., P.R.J. Pena, J.L.B. Vaceslada, A. Martin, M.A.M. Santos and E.R. Gomez, 2000. Removal of phenol compounds from olive mill wastewater using Phanerochate chrysosporiyum, Aspergillus niger, Aspergillus terreus and Gertrichum candidum. Process Biochem., 35: 751-758.

Gavalla, H.N., I.V. Skiadas and G. Lyberatos, 1996. Anaerobic codigestion of agricultural instries wastewaters. Water Sci. Technol., 34: 67-75.

Gharsallah, N., 1993. Production of single cell protein from olive mill wastewater by yeast. Environ. Technol., 14: $391-395$.

Gharsallah, N., M. Labat, F. Aloui and S. Sayadi, 1999. The effect of Phanerochaete chrysosporium pretreatment of olive mill wastewaters on anaerobic digestion. Resour. Conserv. Recycl., 27: 187-192. 
Gray, N.F., 1999. Water Technology: An Introduction for Environment Scientists and Engineers. Arnold Publishers, London, pp: 548.

Hamdi, M. and R. Ellouz, 1992a. Use of Aspergillus niger to improve filtration of olive mill waste-waters. J. Chem. Technol. Biotechnol., 53: 195-200.

Hamdi, M. and R. Ellouz, 1992b. Bubble column fermentation of olive mill wastewaters by Aspergillus niger. J. Chem. Technol. Biotechnol., 54: 331-335.

Hamdi, M., 1991. Effects of agitation and pretreatment in the batch anaerobic digestion of olive mill wastewater. Bioresour. Technol., 36: 173-178.

Hamdi, M., M. BouHamed and R. Ellouz, 1991a. Optimization of the fermentation of olive mill waste waters by Aspergillus niger. Applied Microbiol. Biotechnol., 36: 285-288.

Hamdi, M., A. Khadir and J.L. Garcia, 1991b. The use of Aspergillus niger for the bioconversion of olive mill waste-waters. Applied Microbiol. Biotechnol., 34: 828-831.

Hamdi, M., J.L. Garcia and R. Ellouz, 1992. Integrated biological process for olive mill wastewater treatment. Bioprocess Biosyst. Eng., 8: 79-84.

Hwo, C.S. and G. Lettinga, 1997. Acute toxicity of oleate to ecetate-utilizing methanogens in mesophilic and thermophilic anaerobic sludges. Enzyme Microbial Technol., 21: 297-301.

Khabbaz, M.S., M. Vossoughi and M. Shakeri, 2004. Performance of an anaerobic baffled reactor for olive mill wastewater treatment. Proccedings of the 39th Central Canadian Symp. On Waster Quality Research, Burlington, Canada.

Kissi, M., M. Mountadar, O. Assobhei, E. Gargiulo, G. Palmieri, P. Giardina and G. Sannia, 2001. Roles of two white-rot basidiomycete fungi in decolorization and detexofication of olive mill waste water. Applied Microbiol. Biotechnol., 57: 221-226.

Knupp G., G. Rucker, A. Ramos-Cormenzana, S.E.G. Hoyos, M. Neugebauer and T. Ossenkop, 1996. Problems of identifying phenolic compounds during the microbial degradation of olive mill wastewater. Int. Biodeteriorat. Biodegradat, 38: 277-282.

Lettinga, G., 1995. Anaerobic digestion and wastewater treatment systems. Antoine Leeuwenhoek, 67: 3-28.

Marques, I.P., 2001. Anaerobic digestion treatment of olive mill wastewater for effluent reuse in irrigation. Desalination, 137: 233-239.

Marques, I.P., A. Texeira, L. Rodrigues, S.M. Dias and J.M. Novais, 1997. Anaerobic co-treatment of olive mill and piggery effluents. Environ. Technol., 18: $265-274$.
Martin, A., R. Borja and A. Chica, 1993. Kinetic study of an anaerobic fluidized bed system used for the purification of fermented olive mill wastewater. J. Chem. Technol. Biotechnol., 56: 155-162.

Martin, A., R. Borja, I. Garcia and J.A. Fiestas, 1991. Kinetics of methane production from olive mill wastewater. Process Biochem., 26: 101-107.

Niaounakis, M. and C.P. Halvadakis, 2006. Olive Processing Waste Management: Literature Review and Patent Survey. 2nd Edn., Elsevier, Amsterdam, The Netherlands, pp: 514.

Nieto, L.M., S.E.G. Hoyos, F.C. Rubio, M.P.G. Pareja and A.R. Cormenzana, 1993. The biological purification of waste products from olive oil extraction. Bioresour. Technol., 43: 215-219.

Papadelli, M., A. Roussis, K. Papadopoulou, A. Venieraki, I. Chatzipavlidis, P. Katinakis and K. Balis, 1996. Biochemical and molecular characterization of an Azobacter vinelandiim strain with respect to its ability to grow and fix nitrogen in olive mill wastewater. Int. Bioteriorat. Biodegradat., 38: 179-181.

Papadimitriou, E.K., I. Chajipavlidis and C. Balis, 1997. Application of composting to olive mill wastewater treatment. Environ. Technol., 18: 101-107.

Paredes, C., A. Roig, M.P. Bernal, M.A. SanchezMonedero and J. Cegarra, 2000. Evolution of organic matter and nitrogen during co-composting of olive mill wastewater with solid organic wastes. Biol. Fert. Soils, 3: 222-227.

Paredes, C., J. Cegarra, M.A.S. Monedero, E. Galli and Fiorelli, 1996. Composting of Fresh and Pond-Stored Olive Mill Wastewater by the Rutgers System. In: The Science of Composting, De Bertoldi, M., P. Sequi, B. Lemmes and T. Papi (Eds.). Blackie Academic and Professional, Glasgow, UK.

Paredes, C., M.P. Bernal, J. Cegarra and A. Roig, 2002. Bio-degradation of olive mill wastewater sludge by its co-composting with agricultural wastes. Bioresour. Technol., 85: 1-8.

Perez, J., T. De la Rubia, O.B. Hamman and J. Martinez, 1998. Phanerochaete flavido-alba laccase induction and modification of manganese peroxidase isoenzyme pattern in decolorized olive oil mill wastewaters. Applied Environ. Microbiol., 64: 2726-2729.

Piperidou, C., C. Cah idou, C. Stalikas, K. Soulti, G. Pilidis and C. Balis, 2000. Bioremediation of olive mill wastewater: Chemical alterations induced by Azobacter vinelandii. J. Agric. Food Chem., 48: 1941-1948.

Ramos-Cormenzana, A., B. Juarez-Jimenez and M.P. Garcia-Pareja, 1996. Antimicrobial activity of olive mill wastewaters (alpechin) and biotransformed olive oil mill wastewater. Int. Bioteriorat. Biodegradat., 38: $283-290$. 
Ranalli, A., 1992. Microbiological treatment of oil mill wastewaters. Grasas Aceites, 43: 12-19.

Rozzi, A., R. Passino and M. Limoni, 1989. Anaerobic treatment of olive mill effluents in polyurethane foam bed reactors. Process Biochem., 26: 68-74.

Sanjust, E., R. Pompei, A. Rescigno, A. Rinaldi and M. Ballero, 1991. Olive milling wastewater as a medium for growth of four Pleurotus species. Applied Biochem. Biotechnol., 31: 223-235.

Sayadi, S. and R. Ellouz, 1992. Decolorization of olive mill wastewaters by the white-rot fungus Phanerochaete chrysosporium: Involvement of the lignin-degrading system. Applied Microbiol. Biotechnol., 37: 813-817.

Sayadi, S. and R. Ellouz, 1995. Roles of lignin peroxidase and manganese peroxidase from Phanerochaete chrysosporium in the decolorization of olive mill wastewaters. Applied Environ. Microbiol., 61: 1098-1103.

Tomati, U., E. Galli, G. DiLena and R. Buffone, 1991. Induction of Laccase in Pleurotus ostreatus mycelium grown in olive oil wastewaters. Agrochimica, 35: 275-279.

Tomati, U., E. Galli, L. Paseti and E. Volterra, 1995. Bioremediation of olive mill wastewaters by composting. Waste Manage. Res., 13: 509-518.

Tsioulpas, A., D. Dimou, D. Iconomou and G. Aggelis, 2002. Phenolic removal in olive oil mill wastewater by strains of Pleurotus spp. in respect to their phenol oxidase (laccase) activity. Bioresour. Technol., 84: 251-257.
Ubay, G. and I. Ozturk, 1997. Anaerobic treatment of olive mill effluents. Water Sci. Technol., 36: 287-294.

Vinciguerra, V., A. D'Annibale, E. Gacs-Baitz and G.D. Monache, 1997. Biotransformatiuon of tyrosol by whole-cell and cell-free preparation of Lentinus edodes. J. Mol. Catal. B: Enzymatic, 3: 213-220.

Vinciguerra, V., A. D'Annibale, G.D. Monache and G.G. Sermanni, 1995. Correlated effects during the bioconversion of waste olive waters by Lentinus edodes. Bioresour. Technol., 51: 221-226.

Vlyssides, A.G., M. Loizidou and A.A. Zorpas, 1999. Characteristics of solid residues from olive oil processing as bulking agents for co-composting with industrial wastewaters. J. Environ. Sci. Health A, 34: $737-748$

Yesilada, O., K. Fiskin and E. Yesilada, 1995. The use of white rot fungus Funalia trogii (Malatya) for the decolourization and phenol removal from olive mill wastewater. Environ. Technol., 16: 95-100.

Yesilada, O., S. Sik and M. Sam, 1998. Biodegradation of olive oil mill wastewater by Coriolus versicolor and Funalia trogii: Effects of agitation, initial COD concentration, inoculum size and immobilization. World J. Microbiol. Biotechnol., 14: 37-42.

Zouari, N. and R. Ellouz, 1996a. Microbial consortia for the aerobic degradation of aromatic compounds in olive oil mill effluent. J. Ind. Microbiol., 16: 155-162.

Zouari, N. and R. Ellouz, 1996b. Toxic effect of coloured olive compounds on the anaerobic digestion of olive oil mill effluent in UASB-like reactors. J. Chem. Technol Biotechnol., 66: 414-420. 